\title{
ORNITHOLOGICAL NOTES.
}

By Alfred J. North, C.M.Z.S., Ornithologist.

\section{VIII.-DESCRIPTION oF A NEW SPECIES oF HONEY- EATER FROM NORTH QUEENSLAND.}

\section{Ptilotis leilavalensis, sp. nov.}

Adult.-General colour above pale ashy-brown tinged with yellow, the upper tail-coverts more distinctly shaded with yellow; scapulars and upper wing-coverts like the back; quills brown, strongly washed with bright olive yellow, the apical portion of the outer webs of the primaries and the tips of the secondaries having whitish edges; tail-feathers brown with whitish tips, the two central feathers, and outer webs of the remainder washed with bright olive yellow; lores, forehead, sides of the head, cheeks and ear-coverts bright olive yellow ; behind the ear-coverts a patch of silky-white feathers ; chin, throat, and fore neck pale olive-yellow passing into fawn-white, tinged with yellow on the breast and abdomen, lower portion of the abdomen and the under tail-coverts pale yellow; bill black; legs and feet fleshy-brown. Total length of skin 6 inches, wing $2 \cdot 8$, tail $2 \cdot 7$, bill $0 \cdot 42$, tarsus $0 \cdot 75$. land.

Habitat. Fullerton River, Burke District, North Queens-

Type. In the Australian Museum, Sydney.

Observations. This species, which will be vernacularly known as the Lesser White-plumed Honeyeater, is allied to P. penicillata and $P$. flavescens. From the former it may be distinguished principally by its smaller size, more brightly coloured head, and otherwise generally paler plumage, also by the absence of the blackish line which separates the silky-white patch of feathers from the earcoverts. In size, and general colour of plumage, except the earcoverts, it closely approaches $P$. flavescens.

The specimen from which the above description is taken was presented to the Trustees by Dr. W. Macgillivray of Hamilton, Victoria. It was obtained by his brother, Mr. A. S. Macgillivray, of Leilavale Station, Fullerton River, thirty miles east of Cloncurry Township, North Queensland, who states that these birds are fairly common in the Tea-trees along the river. The nest and eggs were secured at the same time, but the latter were unfortunately broken. 